\title{
A Byzantine business letter and account from the collection of the Oslo University Library*
}

\author{
Joanne Vera Stolk (University of Oslo)
}

\begin{abstract}
This Byzantine papyrus from Aphrodite preserves the middle part of a business letter on the recto and the address on the verso. The letter concerns an estate of the monastery of Apa Sourous. The verso contains an account of expenses which connects the papyrus to the well-known archive of Dioscorus.
\end{abstract}

Keywords: Byzantine papyrus, business letter, monastery of Apa Sourous, account, archive of Dioscorus

P.Oslo inv. 523

$18.3 \times 22.6 \mathrm{~cm}$

VI, Aphrodite

This Byzantine papyrus from Aphrodite was acquired to the collection of the Oslo University Library among a group of Roman papyri from the Arsinoites. ${ }^{1}$ The recto preserves the middle part of a business letter, complete with an address on the verso. The verso further contains an account of expenses. The papyrus probably originates from the well-known archive of Dioscorus. Below I present the editions of the letter and the account separately.

\section{Business letter by Ammonios}

It is a medium brown papyrus, broken off at the right and left hand side, but the upper $(2.5 \mathrm{~cm})$ and lower $(2 \mathrm{~cm})$ margins are fully preserved (except for a gap at the upper right hand side in lines 1-2). The text on the recto is written transversa charta. If the total width of the roll was ca. $30 \mathrm{~cm}$, cf. the size of the Byzantine letters in CPR XXV and H. Harrauer, Handbuch der griechischen Paläographie. Textband (2010) 54, and the cross or saltire pattern on the verso was centred, about a quarter of the text is missing from the left hand side and a few letters from the right hand side (cf. 1. 4). A kollesis, upper over lower, is visible above line 1 and between line 7 and 8 . There is some damage to lines 2,4 , below 5,7 , below 8 and below 9 which corresponds to some of the lighter areas at the verso of the

\footnotetext{
* I would like to thank A. Maravela, K.A. Worp and J.-L. Fournet for their comments on previous versions of this papyrus edition.

${ }^{1}$ The inventory numbers 434-539 were purchased in 1923 through a joint purchase with the British Museum and the Michigan and Columbia universities.
} 
sheet and is probably caused by the folding of the piece horizontally from the bottom upwards.

The recto is written in an experienced, cursive hand common in Byzantine papyri from the sixth century CE, cf. P.Oxy. XVI 1885 (509); P.Oxy. I 144 (580) and P.Heid. III 247 (1.-25.11.598 or 2.-26.11.599; BL X, 84). Parallels can also be found among the texts from the sixth century Dioscorus' archive, e.g. P.Cair. Masp. I 67067, $\mathrm{R}^{\circ} ; 67076, \mathrm{R}^{\circ}$ and III $67282, \mathrm{R}^{\circ}$. The verso contains the address of this letter in a chancellery hand along the fibres at the top of the papyrus, see P.Harrauer 56, p. 203-204, for comments on this style of writing.

The letter seems to concern one of the holdings of the Apa Sourous monastery. This monastery was located in the Antaiopolites, near the village of Aphrodite, cf. A. Calderini, Dizionario Geografico I.2 (1966) 333 and P. Barison, "Ricerche sui monasteri dell'Egitto bizantino ed arabo", Aegyptus 18 (1938) 114-115, Nr. 36. The monastery is attested in several sixth century texts from Aphrodite: P.Cair. Masp. I 67087, 6 (27.12.543); I 67110, 27 (25.07.565); II 67133, 1 (ca. 541; BL XII, 46); II 67139, VI V² (541-546; BL IX, 43); P.Freer $1+2=$ SB XX 14669, 4ff. (524) and P.Mich. XIII 667, 6-7, 35 (mid VI), all belonging to the Dioscorus archive. During the seventh and eighth centuries the monastery is attested in CPR XXIV 31, 7 (mid-second half VII) and the tax register P.Lond. IV $1419+$ SB XX 15099 (716-717; BL V, 56). This business letter mentions the $\pi \rho 0 \varepsilon \sigma \tau \omega \varsigma$ (1. 1), the manager of the estates belonging to the property of the monastery, a specific estate ( $\tau$ ò $\kappa \tau \hat{\eta} \mu \alpha, 1.3$ ) of which the name is not preserved (it might have been at the end

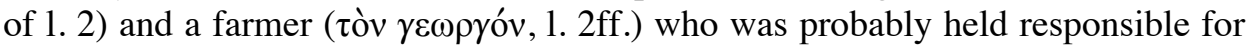
the cultivation of the estate. The monastery of Apa Sourous was an important landholder in the area and it leased out land to private landowners, who could sublease it to a $\gamma \varepsilon \omega \rho \gamma$ óc. Dioscorus is known to have been a middleman-lessee for the Apa Sourous monastery, see J. Keenan, "Absentee Landlordism at Aphrodite", $B A S P 22$ (1985) 157. The responsibility for the payment of the taxes on leased land was also transferable, see M. Mirković, "Count Ammonios and Paying Taxes in the Name of Somebody Else", Pap. Congr. 25 (2010) 568-569.

The well-known count and landowner Ammonios might have been the sender of this letter (see n. to $\mathrm{V}^{\circ}$ ). He had received a message from the $\pi \rho 0 \varepsilon \sigma \tau \omega \varsigma \varsigma$ of the monastery of Apa Sourous concerning the produce of the vineyard of the estate. The monastery of Apa Sourous owned land in as many as twenty topoi and the rents from these holdings added up to more than 137 artabai of grain and also payments in oil and wine, cf. L.S.B. MacCoull, "Notes on the Social Structure of Late Antique Aphrodite", BSAC 26 (1984) 71-74 and J. Gascou, Fiscalité et société en Égypte byzantine (2008) 282, n. to 1. 4. In the lease contract P.Mich. XIII $667,14-19$ (mid VI) the rent of an estate of the monastery included the payment


wine. In our letter the produce of the vineyard of the estate yielded a total of only

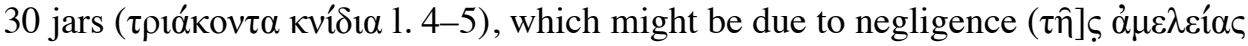




The exact content of the letter is obscured by the missing parts on the left and right hand side of the papyrus, but some phrases can be supplemented due to the effusive and repetitive style of this Byzantine letter. Recurring figures are the $\pi \rho 0 \varepsilon \sigma \tau \omega$ ' $\varsigma$ of the monastery (1. 1,7 and perhaps 9) and the farmer (1. 2,6 and 8), who might have been responsible for the cultivation. It seems that the $\pi \rho 0 \varepsilon \sigma \tau \dot{c} \varsigma$ and/or Ammonios wanted to allow the farmer to continue to cultivate the same estate $(1.6,9)$ despite of the problem that has arisen.

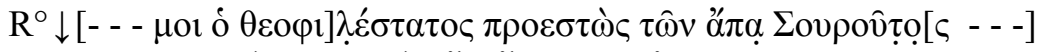

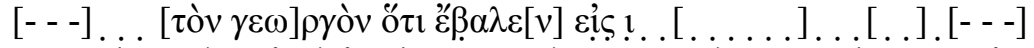

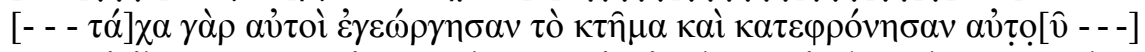

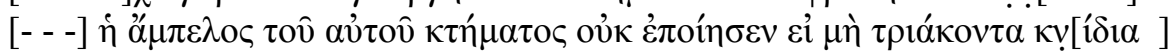

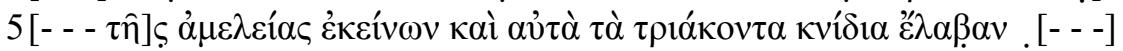

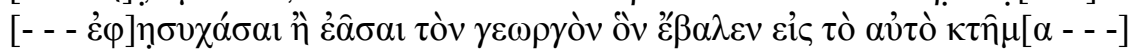

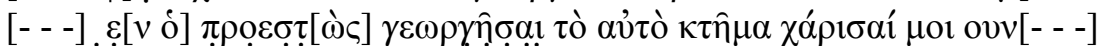



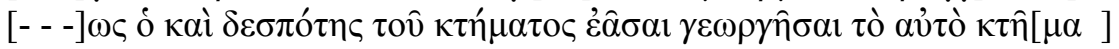

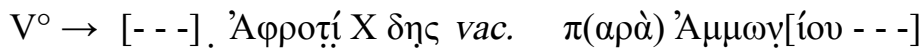

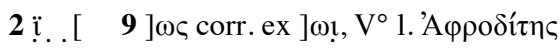

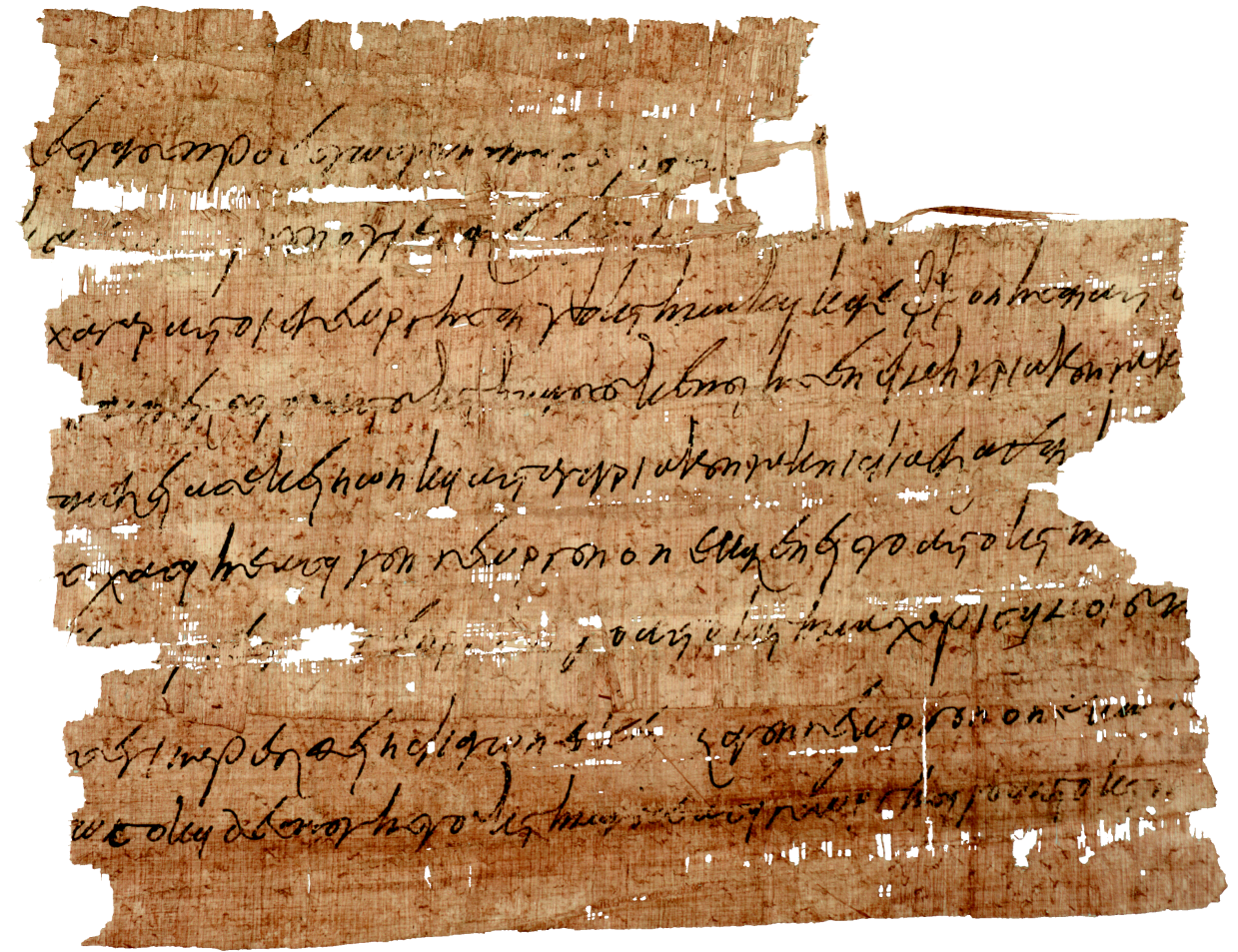

P.Oslo inv. $523 \mathrm{R}^{\circ}$ : Business letter by Ammonius 


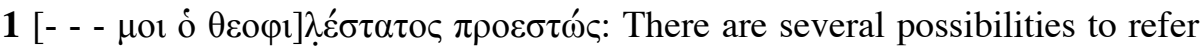

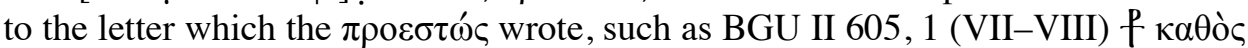

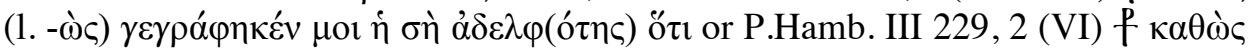

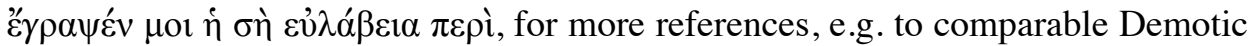
and Coptic epistolary formulae, see CPR XXV 34, n. to 1. 2. Considering the total

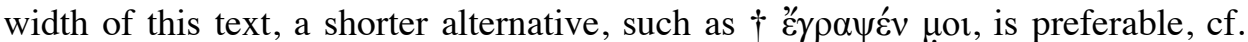

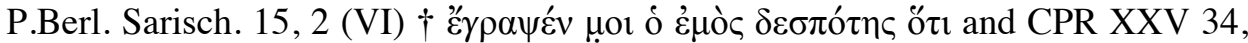

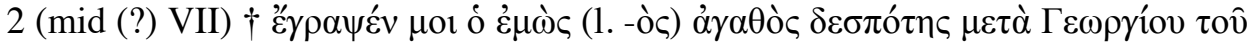

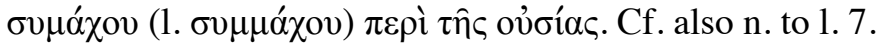

$\theta \varepsilon \circ \varphi 1] \lambda \varepsilon \dot{\varepsilon} \sigma \alpha \tau \tau o c:$ Possible supplements for this honorific title include $\varepsilon \hat{\lambda} \lambda \alpha-$


Untersuchungen zu den abstrakten Anredeformen und Höflichkeitstiteln (1949)

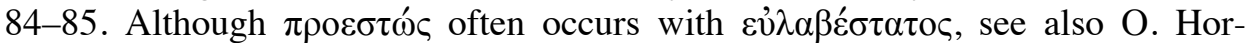
nickel, Ehren- und Rangprädikate in den Papyrusurkunden (1930) 16-17, the

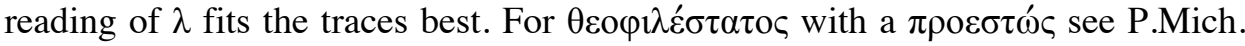
XIII 667, 7, 35-36 (mid VI), where it is also used for the $\pi \rho 0 \varepsilon \sigma \tau \omega \varsigma$ of the Apa Sourous monastery, and further P.Cair. Masp. II 67170, 6-7 (15.-24.04.562-564; ZPE 145, 2003, 243); II 67171, 7-8 (16.04.564-565; ZPE 145, 2003, 243) and P.Fouad $88, \mathrm{~V}^{\circ} 1(\mathrm{VI})$.

$\pi \rho 0 \varepsilon \sigma \tau \omega ́ c:$ The head of the monastery and the manager of the estates belonging

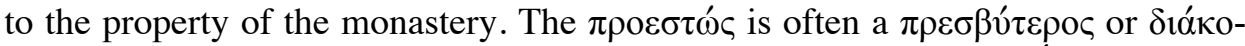
vos, see E. Wipszycka, Moines et communautés monastiques en Égypte (2009)

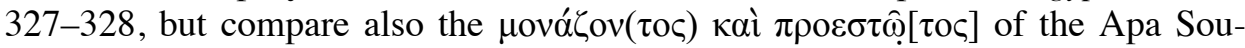
rous monastery in P.Mich. XIII 667, 7, 35-36 (mid VI).

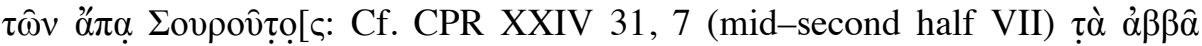


des Abba Surus", but a full reference to the place or premises of the monastery might have followed as well.

$2[---] \ldots$. [ by $\pi \varepsilon \rho \hat{~}+$ gen. or ö $\tau$ in line 2 , see $n$. to 1.1 for parallels to this formula. The traces

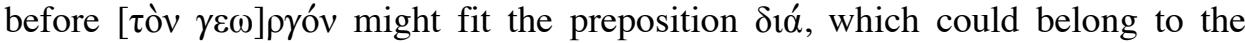

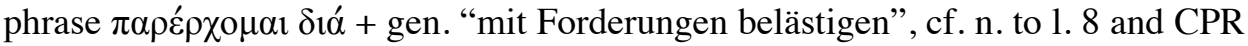

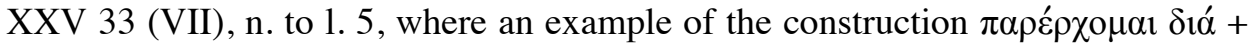
acc. is mentioned (P.Vindob. G 16791, 7). Another possible reading is ] $\alpha$, a first person verbal ending.

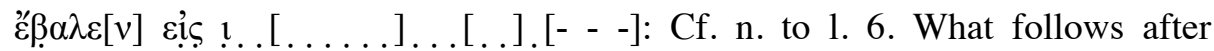
" $\beta \alpha \lambda \varepsilon[v]$ sị might be part of the introduction of the estate by providing a name or referring to its location, cf. e.g. P.Hamb. I 68, 26 (548 or 563; BL XII, 83)

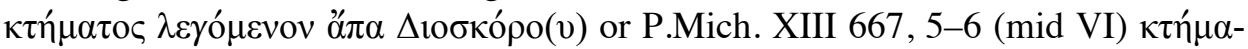


voc is attested, e.g. the tax register P.Lond. IV 1419, VIII 139ff. (716-717; BL V,

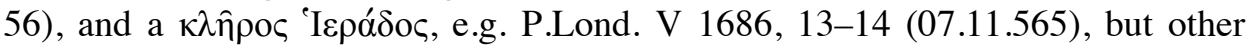
names are possible as well. 


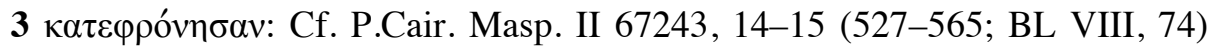

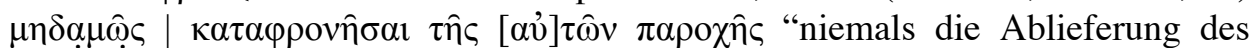
Kornpachtzinses vernachlässigen”, see F. Preisigke, Wörterbuch I (1925) 770.

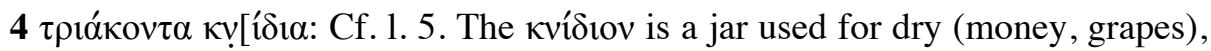
semi dry (garum, olives), but most frequently for liquid goods such as wine and olive oil, see N. Kruit \& K. Worp, "Geographical Jar Names", APF 46.1 (2000) 104-110. It could be that the rent on this estate was paid in $\kappa v i \delta 1 \alpha$ of wine, cf. the mention of a vineyard in 1.4 and P.Mich. XIII 667, 14-19 (mid VI), in which the rent consisted of the taxes, an additional 20 artabai of corn and 50 vessels of sweet

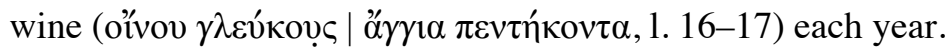

5 ' $\lambda \alpha \beta \alpha v$ : The reading of the $\beta$ is problematic, but this hook-shaped sign does not resemble any other letter either. The verb '̋ $\lambda \alpha \beta \alpha \nu$ contains the ending of the first aorist to a second aorist form, cf. F.T. Gignac, Grammar II (1981) 335-345, see for '̌ $\lambda \alpha \beta \alpha v$ p. 342, and B. Mandilaras, The Verb in the Greek Non-Literary Papyri (1973) 148-154.

.[- - ]: The traces resemble $\kappa$ or $\eta$.

$6 \dot{\varepsilon} \varphi] \eta ̣ \sigma \chi \chi \alpha ́ \sigma \alpha l:$ Possible supplements include $\dot{\eta} \sigma u \chi \alpha ́ \zeta \omega$ "sich beruhigen, sich ruhig verhalten, sich zur Ruhe setzen, bewenden lassen, auf etw. verzichten ( $\tau$ iví)" and the derived verbs $\dot{\alpha} \varphi \eta \sigma v \chi \alpha \dot{\zeta} \zeta \omega$ "sich beruhigen"; $\dot{\varepsilon} \varphi \eta \sigma v \chi \alpha \dot{\zeta} \omega$ "sich bei etw. beruhigen, zufriedengestellt sein"; $\kappa \alpha \theta \eta \sigma v \chi \alpha \dot{\zeta} \omega$ "sich beruhigen, sich zufrieden geben”, see F. Preisigke, Wörterbuch I (1925) 662, 246, 632 and 715. The traces before the sigma could very well belong to the connection between $\eta$ and $\sigma$. The

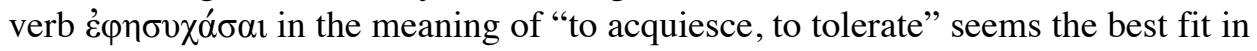
this construction, cf. SB XVIII 13320, 5ff. (613-641).


$6,8)$. He is said to have been "put into" the estate, see LSJ s.v. $\beta \alpha ́ \alpha \lambda \omega$ A. II.6, and

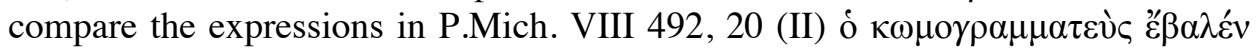

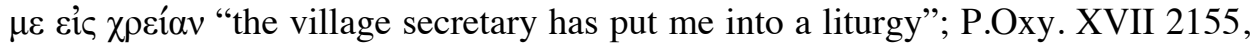

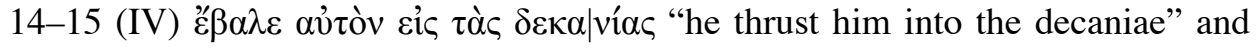

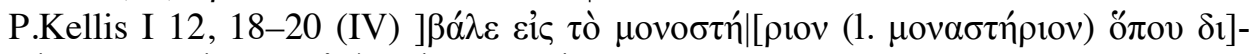

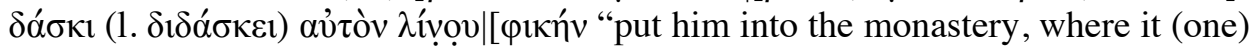
teaches him the linen-weaving trade". In practice this $\gamma \varepsilon \omega \rho \gamma$ ó $̧$ was maybe "put in charge" of the cultivation of the land and he might also have been responsible for the contribution of the rent and dues, see M. Mirković, "Count Ammonios and Paying Taxes in the Name of Somebody Else", Pap. Congr. 25 (2010) 568-569.

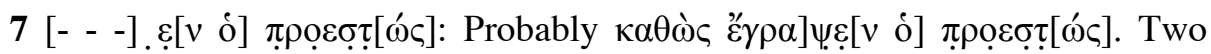
vertical strokes are preserved above the lacuna at the beginning of line 7 . Because it is slightly leaning forward, the second one seems most compatible with the upper part of an $\varepsilon$. For the same reason the first stroke might fit a $\psi$ better than the upper part of the $\kappa$ in this hand. This makes a supplement $\left.\varepsilon^{\prime} \gamma \rho \alpha\right] \psi \varepsilon[v$ more likely than for example $\gamma \varepsilon \gamma \rho \alpha \dot{\varphi} \varphi] \kappa \varepsilon \in[v$, cf. n. to 1.1 . 
ov .[- - - ]: The traces point to a $\tau$ or a $v$, so ov $\tau[$, perhaps ovँ $\tau[\omega \varsigma$, or oṿ̂ are possible.

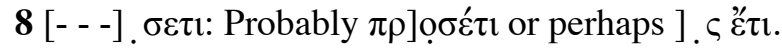

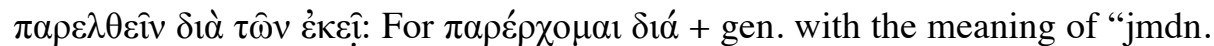
in Sachen der Besteuerung heranziehen (heimsuchen)" see H. Ljungvik, Beiträge zur Syntax (1932) 24-25, and CPR XXV 33 (VII), n. to 1. 5.

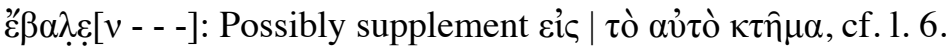

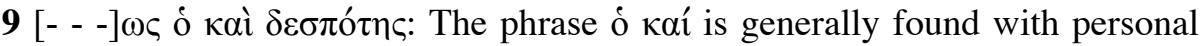
names. The title $\delta \varepsilon \sigma \pi$ ó $\tau$ c was sometimes used to refer to a superior, such as the

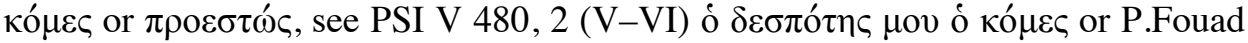

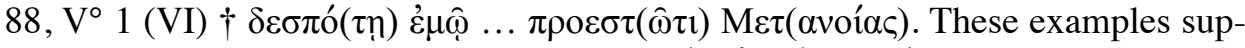

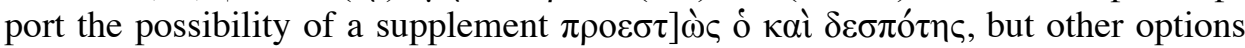
for the interpretation of ] $\omega \varsigma$, such as another function or title, cannot be excluded.

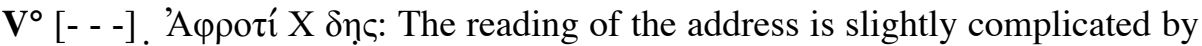
the cross or saltire pattern in the middle of the address. After the cross the letters $\delta$ o $\varsigma$ or $\delta \eta\rceil$ are visible. Frequent formulae for the address on the verso of these

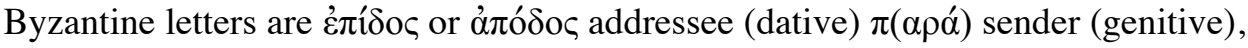
e.g. P.Mert. I 46, Vº (late V-early VI; BL VIII, 208); BGU II 605, V (VII-VIII), or addressee (dative) and sender (nominative), e.g. P.Apoll. 32, $\mathrm{V}^{\circ}$ (second half VII; BL VIII, 10). The usage of dó $\varsigma$ is rare and usually occurs at the beginning of the address followed by the addressee (dative), cf. P.Oxy. XVII 2156, V' (late IVV) and P.Ant. II 94, $\mathrm{V}^{\circ}$ (VI). Therefore it is unlikely that we have here a single $\delta$ ó $\varsigma$ in the middle of the address, but rather a continuation of the addressee, $\mathrm{cf}$.

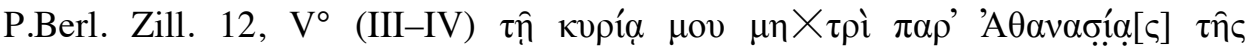

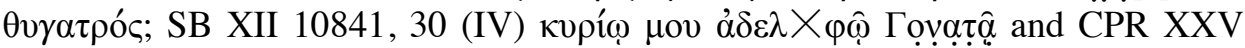

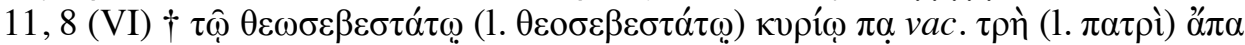
Ko $\lambda \lambda$ ov $\theta \omega$, where the remains of a cross are visible before and after the vacat, see Tafel 10 and $n$. to 1. 8. The genitive of the village of Aphrodite then should have

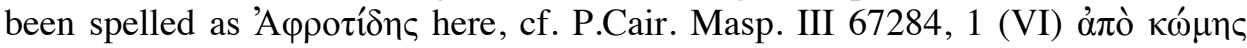

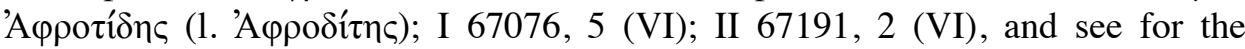
possible inversion of consonants and the interchange of $\delta$ and $\tau$ intervocalically F.T. Gignac, A Grammar of the Greek papyri I (1976) 82-83, 154. The full

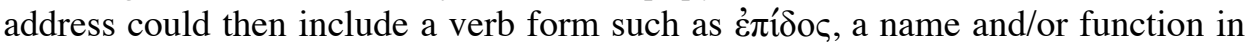

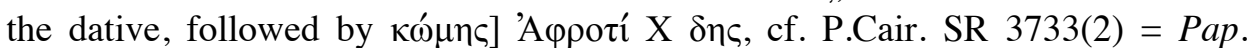

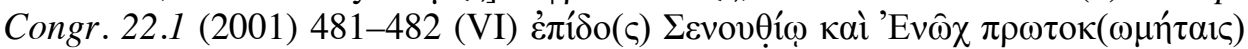

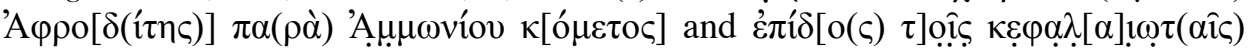


be visible under the lacuna before 'A $\varphi \rho o \tau$ ' $\mathrm{X} \delta \eta \varsigma$, but it is impossible to say whether $\kappa \omega ́ \mu \eta \varsigma$ or something else was written there, cf. also the addressee in

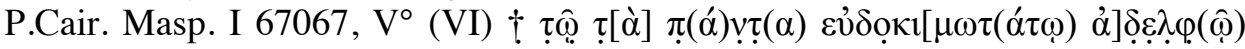

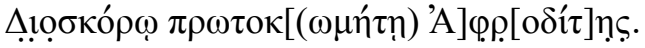


'A $\mu \mu \omega v[$ [iov - - - ]: Up to 13 people with this name are attested in sixth century Aphrodite, cf. G.R. Ruffini, A Prosopography of Byzantine Aphrodite (2011) 1720. A monk Ammonios (nr. 8) is attested in connection to the monastery of Apa Sourous in P.Cair. Masp. II 67133, 1 (ca. 541; BL XII, 46). The most interesting candidate is the famous count Ammonios (nr. 1), known from the texts of the Dioscorus archive. He is mentioned in connection with several monasteries in the mid sixth century AD, such as the monastery of Apa Apollo in PSI VIII 933, 3-4 (24.-28.08.538). Furthermore, the address of this letter finds a close parallel in the formulae used as headings in a dossier of administrative letters written by Dioscorus, see J.-L. Fournet, "Du nouveau dans les archives de Dioscore d'Aphrodité", Pap. Congr. 22.1 (2001) 481-482 and previous note. These formulae resemble the addresses of letters originating from count Ammonios.

The most highly favoured manager of the [...] of Apa Sourous [has written to me] [...] the farmer that he put into [...] for they might have cultivated the estate and neglected it [...] the vineyard of the same estate produced only thirty jars [...] of the negligence of them and they took these thirty jars [...] to tolerate or to allow the farmer that he put into the same estate [... as] the manager [wrote] to cultivate the same estate, do me a favour [...] to impose with taxes the men there but the farmer that he put [into the same estate ...] and lord of the estate to allow to cultivate the same estate. (Verso) [To ...] of Aphrodite, from Ammonios [...].

\section{Account of expenses ${ }^{2}$}

In the middle of the verso, turned $90^{\circ}$ anti-clockwise, across the fibres are the remains of an account of expenses. At the top of the sheet above the heading of the list are the traces of the last three lines of another account. The main list consists of 14 lines with both upper $(2 \mathrm{~cm})$ and lower $(6.7 \mathrm{~cm})$ margins. In $1.12 \mathrm{a}$ note is added to the main account. The last 6 entries on the list are badly preserved, although some of the amounts $\gamma(1.15)$ and $\beta$ (1.16) are readable.

J.-L. Fournet identified the hand writing as that of the famous Dioscorus, cf. his handwriting in e.g. P.Cair. Masp. I $67097 \mathrm{~V}^{\circ} \mathrm{A}$ (16.12.558 or 573); P.Flor. III 289 (VI) and P.Lond. V 1686 (07.11.565), see L. Del Corso, "Le scritture di Dioscoro", in J.-L. Fournet (ed.), Les archives de Dioscore d'Aphrodité cent ans après leur découverte (2008) 91-95. Most letters, such as the $\rho, \tau, \eta, \lambda$ and the ligatures of $\alpha \varsigma$ and $\alpha \rho$ are very similar indeed. The $\kappa$ is less typical, but he might have written this account in a less formal manner. The first and last attestations of Dioscorus are in P.Cair. Masp. I 67087 (28.12.543; ZPE 26, 1977, 272) and P.Cair. Masp. I 67096 (05.-11.573; BL VII, 34), see J.-L. Fournet, "Archive ou archives de Dioscore? Les dernières années des «archives de Dioscore»", in J.-L. Fournet (ed.), Les archives de Dioscore d'Aphrodité cent ans après leur décou-

\footnotetext{
${ }^{2}$ I would like to thank J.-L. Fournet for his generous help with the reading of the verso. Among others, I owe parts of the readings of $1.5,7$ and 12 to him.
} 
verte (2008) 19-21. If the identification of the hand writing is correct, this papyrus should not be dated any later than $573 \mathrm{CE}$.

The main part of this account of expenses (1.5-12) contains payments to men in various professions, which are possibly connected to the making of clothes

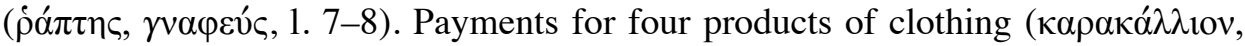

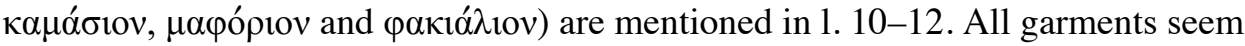
to be Latin loanwords, but this is not uncommon for these types of products, cf. P.Heid. VII 406, p. 176. The items are common and often found in other lists of clothing, see e.g. P.Princ. II 82, 36-45 (481) which contains all four of them.

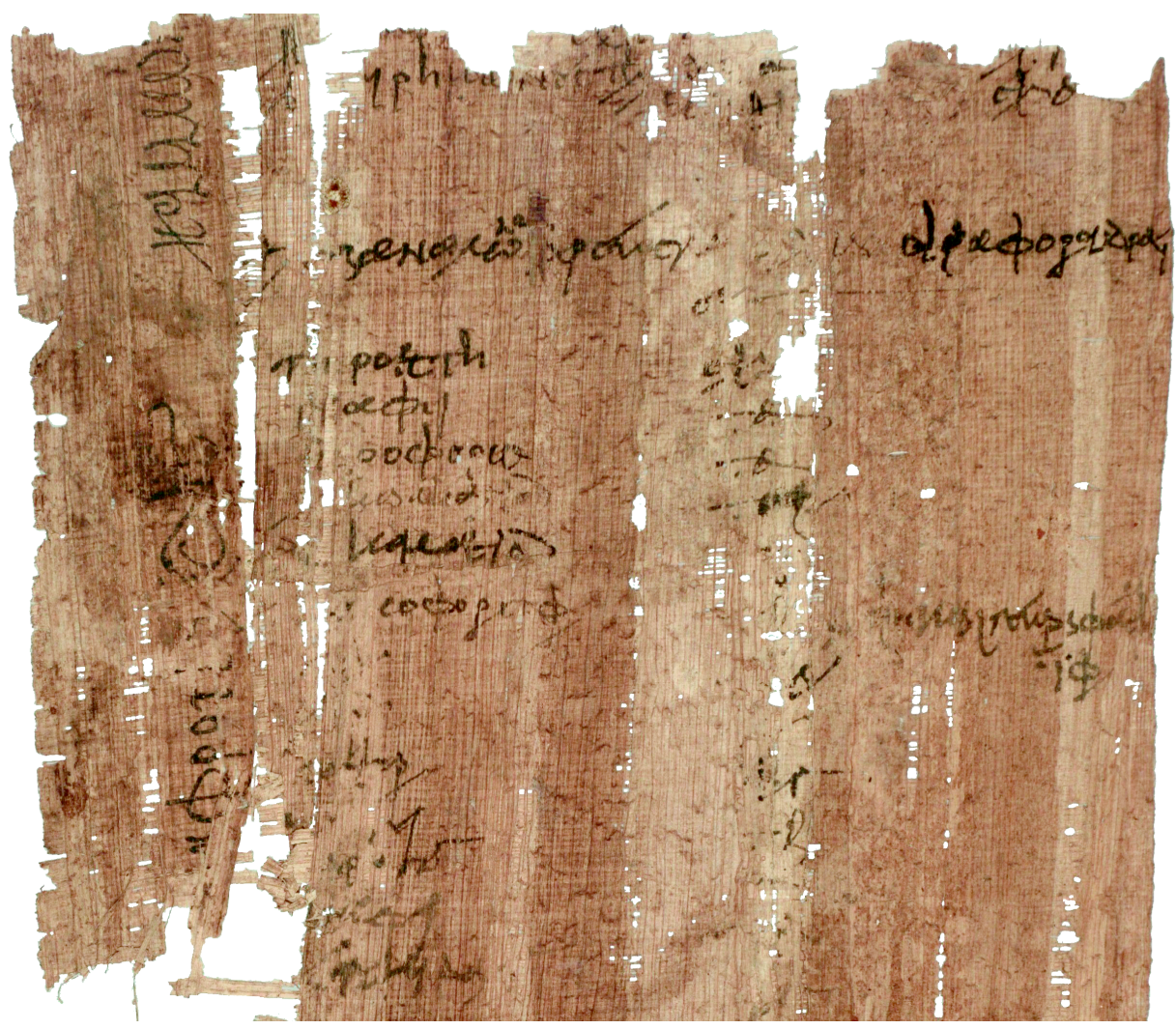

P.Oslo inv. $523 \mathrm{~V}^{\circ}$ : Account of expenses

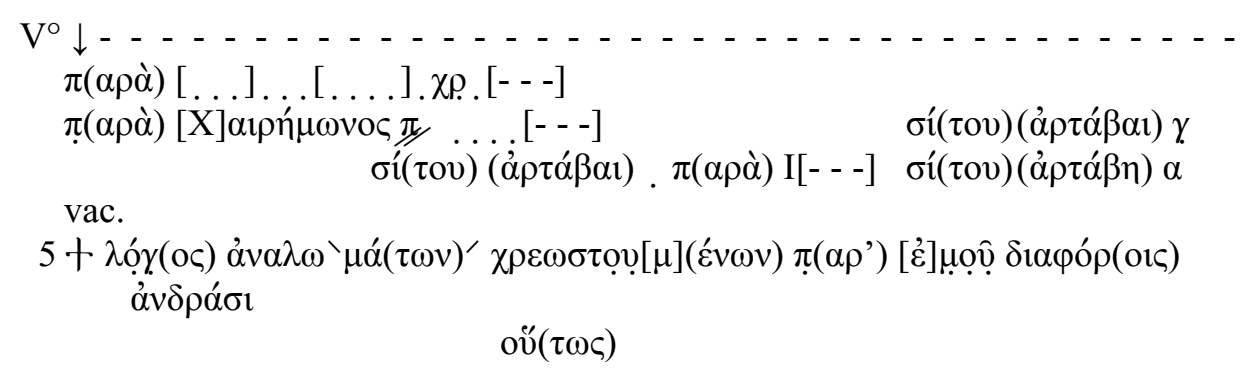




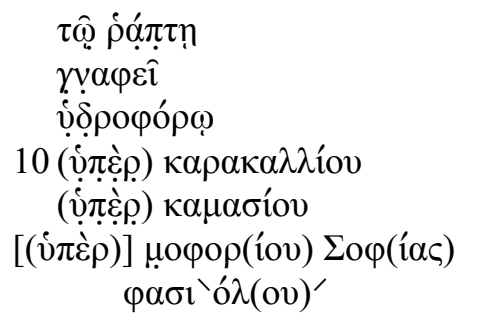

traces of six more lines

$$
\begin{aligned}
& \sigma^{\prime}(\tau \circ v)(\dot{\alpha} \rho \tau .)[.] \\
& (\dot{\alpha} \rho \tau .) \alpha \\
& (\dot{\alpha} \rho \tau .) \alpha \\
& (\dot{\alpha} \rho \tau .) \alpha \\
& (\dot{\alpha} \rho \tau .) \text {. }
\end{aligned}
$$

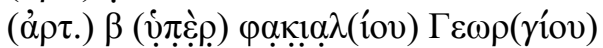

$f^{\prime} \varphi(10 v) \backslash$

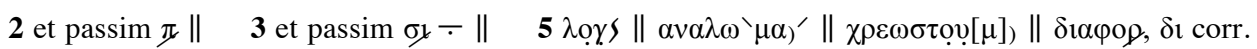

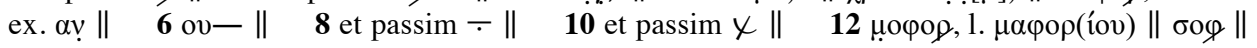
$\varphi \alpha \underline{\operatorname{col} \alpha \lambda \lambda} \| \gamma \varepsilon \omega \rho)$ || $\varphi \alpha \sigma \iota^{\prime} \mathrm{o} \lambda^{\prime} \| \ddot{\varphi} \varphi$

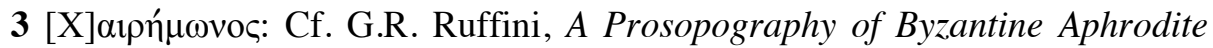
(2011) 139-140. See among others Chairemon (nr. 9) in P.Cair. Masp. II 67141, $\mathrm{V} \mathrm{V}^{\circ} 12$ (VI), an account of expenses written by Dioscorus relating to his family holdings, and cf. n. to 1.12 .

$10 \kappa \alpha \rho \alpha \kappa \alpha \lambda \lambda$ íov: This word for "hooded cloak" is probably taken from Latin caracalla, the originally Gallic cape with hood, cf. S. Daris, Il lessico latino nel Greco d'Egitto (19912) 49, J. Kramer, Von der Papyrologie zur Romanistik, APF Beiheft 30 (2010) 207-217 and CPR X 139, n. to 1. 2. For the connection with Latin cucullus, the hooded cloak worn by monks, see references in P.Heid. IV 333 , n. to 1. 4 , and for references to illustrations of these hooded garments, see D. Montserrat, BASP 29 (1992) 84, n. to 1. 3-4.

$11 \kappa \alpha \mu \alpha \sigma i ́ o v:$ Cf. Latin camisia with the same meaning "shirt", S. Daris, Il lessico latino nel Greco d'Egitto $\left(1991^{2}\right)$ 48-49. J. Kramer has proposed that both the Latin and the Greek word were separately borrowed from a Balkan language in "Zur Rolle von Papyrusbelegen für die Wortgeschichte am Beispiel von cami-

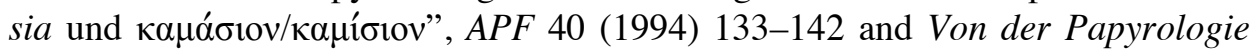
zur Romanistik, APF Beiheft 30 (2010) 195-205; for references and attestations see also P.Heid. VII 406, n. to. 1. 4.

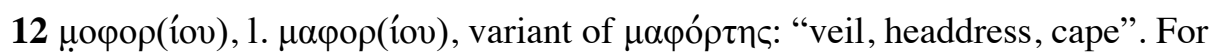

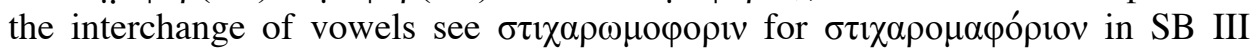
6024, 2, 3, 7 (IV-VII). It might be a loanword from Latin maforte, see S. Daris, Il lessico latino nel Greco d'Egitto $\left(1991^{2}\right) 71$. The Greek word is used for a veil or a cape worn by women, cf. P.Oxy. LIX 4004, 15 (V); P.Princ. II 95, 19 (V; BL X, 165), but maybe also for the headdress of priests, cf. P.Coll. Youtie II 85 (VI). In P.Heid. VII 406, 5ff. (IV-V) the garment is included in a list of clothes belonging

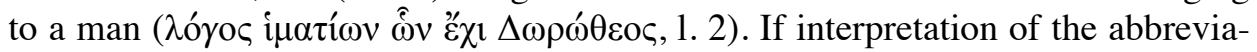
tion $\Sigma o \varphi(i \alpha \varsigma)$ is correct, the $\mu \alpha \varphi$ óplov is a woman's headdress here.

$\Sigma o \varphi(i \alpha c)$ : This abbreviation could refer to Dioscorus' wife Sofia, see J.-L. Fournet, "Archive ou archives de Dioscore? Les dernières années des «archives de 
Dioscore»", in J.-L. Fournet (ed.), Les archives de Dioscore d'Aphrodité cent ans après leur découverte (2008) 22-29.

pakı $\alpha \lambda($ íov): Loanword from Latin faciale, S. Daris, Il lessico latino nel Greco d'Egitto $\left(1991^{2}\right) 114$, with the broad meaning "face-cloth, turban, towel", cf. LSJ s.v. The pakió $\lambda$ iov can be used by men, see P.Tebt. II 406, 18 (266) and women,

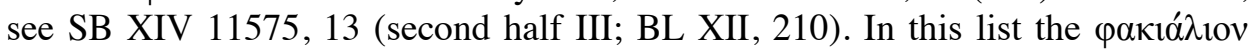
seems to have been a kerchief for a man.

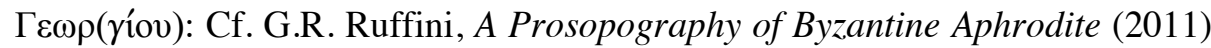
194-198. Several of men with this name are connected to Dioscorus, see e.g. the payment of 1 artabe by Dioscorus to a Georgios in P.Cair. Masp. II 67141, I V 32 (VI).

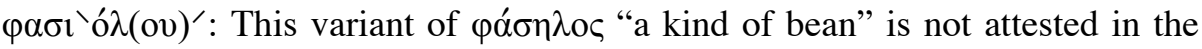

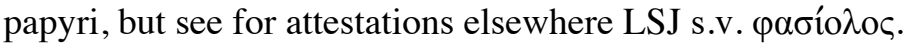

13 ' $\varphi($ (ov): The Egyptian measure ' $\varphi$ iov is regularly used in accounts from the archive of Dioscorus, see P.Cair. Masp. II 67138-67139 (541-546; BL IX, 43); II 67141 (VI); III 67325 (559-560; BL XII, 47). One would expect to find a number after this measure, but there are no traces of that on the papyrus.

From [...], from Xairemon 80 [...], 3 artabai grain, [.] artabai grain, from I[...], 1 artabe grain;

Account of expenses owed by me to various men. As follows: to the clothesmender [.] artabe grain, to the fuller 1 artabe, to the water carrier 1 artabe, on account of a hooded cloak 1 artabe, on account of a shirt [.] artabe, on account of Sofia's headdress 2 artabai, on account of Georgios' kerchief (?) ifion of beans. 